\title{
Wioleta Beczek
}

Uniwersytet SWPS

wioletabeczek@gmail.com

\section{Odpowiedzialność cywilna za opublikowanie artykułu naukowego}

\author{
Civil Responsibility for Publishing a Scientific Article
}

\begin{abstract}
STRESZCZENIE
Odpowiedzialność cywilna za opublikowanie artykułu naukowego jest niejasnym i trudnym tematem. W art. 38 Prawa prasowego nie jest jasno sprecyzowane, kto i kiedy ponosi odpowiedzialność, gdy zostaną naruszone prawa autorskie. Niniejszy artykuł ma na celu próbę wskazania, kiedy naruszane są czyjeś prawa autorskie, co zrobić, gdy zostaną naruszone oraz kto ponosi za takie naruszenie odpowiedzialność, a także ostrzec autorów publikujących swój artykuł naukowy przed taką odpowiedzialnością.
\end{abstract}

Slowa kluczowe: prawa autorskie; odpowiedzialność cywilna; prawo prasowe

\section{WSTĘP}

Każdy, kto chce opublikować artykuł naukowy, musi zdawać sobie sprawę z odpowiedzialności, jaka się z tym wiąże. Zgodnie z art. 38 ust. 1 Prawa prasowego ${ }^{1}$ odpowiedzialność cywilną za naruszenie prawa spowodowane opublikowaniem materiału prasowego ponoszą autor, redaktor lub inna osoba, którzy spowodowali opublikowanie tego materiału (nie wyłącza to odpowiedzialności wydawcy). W zakresie odpowiedzialności majątkowej odpowiedzialność tych osób jest solidarna.

Na początku warto sięgnąć po wyjaśnienie podstawowych pojęć, które pojawiają się w wyżej wskazanym artykule. Wprawdzie pierwszego pojęcia, tj. definicji autora, nie ma w pr. pras., jednak możemy je zaczerpnąć z ustawy z dnia 4 lutego

1 Ustawa z dnia 26 stycznia 1984 r. - Prawo prasowe (Dz.U. nr 5, poz. 24 ze zm.), dalej jako: pr. pras. 
1994 r. o prawie autorskim i prawach pokrewnych ${ }^{2}$, gdzie w art. $8 \S 2$ mamy domniemanie, że twórcą jest osoba, której nazwisko w tym charakterze uwidoczniono na egzemplarzach utworu lub której autorstwo podano do publicznej wiadomości $\mathrm{w}$ jakikolwiek inny sposób w związku z rozpowszechnianiem utworu. W ustawie tej nie ma wyjaśnionego pojęcia autora, ale zgodnie $\mathrm{z}$ art. 8 ust. 1 pr. aut. prawo autorskie przysługuje właśnie twórcy. W art. 7 ust. 2 pkt 6-8 pr. pras. mamy wyjaśnione pojęcia dotyczące redaktora, tj. redaktor to dziennikarz decydujący lub współdecydujący o publikacji materiałów prasowych, redaktor naczelny to osoba posiadająca uprawnienia do decydowania o całokształcie działalności redakcji, zaś redakcja to jednostka organizująca proces przygotowywania (zbierania, oceniania i opracowywania) materiałów do publikacji w prasie. Kolejnym pojęciem jest wydawca - zostało ono zdefiniowane w art. 8 pr. pras.: wydawcą może być osoba prawna, fizyczna lub inna jednostka organizacyjna, choćby nie posiadała osobowości prawnej. W szczególności wydawcą może być organ państwowy, przedsiębiorstwo państwowe, organizacja polityczna, związek zawodowy, organizacja spółdzielcza, samorządowa i inna organizacja społeczna oraz kościół i inny związek wyznaniowy. $\mathrm{W} \S 2$ tego artykułu ustawodawca doprecyzował, że organizacja polityczna, związek zawodowy, przedsiębiorstwo państwowe, organizacja spółdzielcza, samorządowa i inna organizacja społeczna oraz kościół i inny związek wyznaniowy może realizować uprawnienia wydawnicze bezpośrednio lub za pośrednictwem wydawnictw własnych, jak również innych wydawnictw, działających jako nakładca.

Biorąc pod uwagę powyższe definicje, trzeba zauważyć, że są one niekompletne lub niejasne, ponieważ np. autorem może być tylko osoba fizyczna, co jednak w sytuacji, gdy jakaś kancelaria chce wydać artykuł dotyczący prawa rodzinnego, promując swoje usługi w tym zakresie, a zgodnie $\mathrm{z}$ wewnętrzną umową pracownik lub pracownicy, którzy napisali dany tekst, zgadzają się na niepublikowanie ich imion? Mylne jest także samo posługiwanie się pojęciem „twórca”, ponieważ w pr. aut. ustawodawca posługuje się prawie zawsze słowem „twórca”, ale używane jest również określenie „autor” (zob. art. 36 pr. aut.) czy „autorstwo” (zob. art. $115 \S 1$ pr. aut.), zaś w pr. pras. konsekwentnie wszędzie występuje słowo „autor”. W kolejnym wyjaśnieniu pojęcia (redaktor) też jest wiele wątpliwości, ponieważ redaktorem niekoniecznie jest dziennikarz, a pomiędzy powyżej wskazanymi trzema definicjami są czasami niejasne granice. Ponadto zbiory te często się zazębiają lub pokrywają. „Każdy redaktor naczelny jest zarazem »redaktorem«, jak i »dziennikarzem《. Każdy »redaktor« jest »dziennikarzem«. Ilekroć ustawodawca posługuje się pojęciem redaktora, ma na myśli także »redaktora naczelnego«, ale nie odwrotnie"3. Co do ostatniego pojęcia (tj. definicji wydawcy), to czasami jest

2 T.j. Dz.U. z 2017 r., poz. 880 ze zm., dalej jako: pr. aut.

3 Zob. J. Sobczak, Prawo prasowe. Komentarz, Warszawa 2008, s. 340, cyt. za: Prawo prasowe. Komentarz, red. B. Kosmus, G. Kuczyński, Warszawa 2013, komentarz do art. 7, nb 46, s. 107. 
ono - mylnie moim zdaniem - utożsamiane z działalnością zarobkową, ale nie wynika to $\mathrm{z}$ treści przepisu.

Wracając do art. 37 pr. pras., niezbędne jest w tym miejscu omówienie odpowiedzialności ogólnej. Jest ona uregulowana w ustawie z dnia 23 kwietnia 1964 r. Kodeks cywilny ${ }^{4} \mathrm{w}$ następujących artykułach:

- art. 23 i 43 k.c. Art. 23 zawiera otwarty katalog dóbr osobistych, którymi są „powszechnie uznane w społeczeństwie wartości niemajątkowe związane ściśle z osobą człowieka i będące przejawami godności osoby ludzkiej, obejmujące przede wszystkim integralność fizyczną i psychiczną oraz indywidualność człowieka"5, zaś art. 43 wskazuje na odpowiednie stosowanie przepisów o ochronie dóbr osobistych do osób prawnych i - idąc dalej - do ułomnych osób prawnych,

- art. $24 \S 1$ k.c. Dotyczy odpowiedzialności niemajątkowej i majątkowej, tj. wskazuje na dopełnienie czynności potrzebnych do usunięcia skutków naruszenia (np. złożenie oświadczenia w odpowiedniej treści i w odpowiedniej formie, zadośćuczynienie pieniężne lub zapłata odpowiedniej sumy pieniężnej na wskazany cel społeczny),

- art. 448 k.c. Dotyczy odpowiedzialności majątkowej, tj. wskazuje na zadośćuczynienie pieniężne za doznaną krzywdę dla osoby pokrzywdzonej lub zasądzenie odpowiedniej sumy pieniężnej na wskazany cel społeczny, co jest niezależne od innych środków potrzebnych do usunięcia skutków naruszenia.

\section{POJĘCIE DÓBR OSOBISTYCH}

Wyliczone w art. 23 k.c. dobra osobiste są katalogiem otwartym. O tym, czy dana wartość nim jest, decyduje zazwyczaj społeczeństwo, tj. grupa, w której żyjemy, środowisko, w którym przebywamy itp. Nieodłączne jest jednak powiązanie dóbr osobistych z godnością człowieka, którą każdy nabywa z dniem urodzenia, a traci w chwili śmierci. Zgodnie z art. 23 k.c. dobra osobiste „pozostają pod ochroną prawa cywilnego niezależnie od ochrony przewidzianej w innych przepisach". Oznacza to, że poza roszczeniami wskazanymi w prawie prasowym można się domagać od osoby, która naruszyła prawa autorskie, roszczeń wynikających z Kodeksu cywilnego. Co istotne, dobra osobiste posiadają oraz mogą zostać naruszone nie tylko przez osoby fizyczne, ponieważ zgodnie z art. 43 k.c. do osób prawnych stosuje się odpowiednio przepisy dotyczące ochrony dóbr osobistych

4 T.j. Dz.U. z 2018 r., poz. 1025 ze zm., dalej jako: k.c.

5 Tak: Kodeks cywilny. Komentarz, red. E. Gniewek, P. Machnikowski, Warszawa 2017, komentarz do art. 23, s. 57. 
osób fizycznych. „Dobra osobiste osób prawnych - to wartości niemajątkowe, dzięki którym osoba prawna może funkcjonować zgodnie ze swym zakresem działań (art. 43 w zw. z art. 23 k.c.)" ${ }^{\prime \prime}$. Najczęściej naruszane są takie dobra osobiste osób prawnych, jak: tajemnica przedsiębiorstwa, dobra sława i imię, renoma, nazwa, a także nietykalność pomieszczeñ? ${ }^{7}$ W przypadku osób prawnych kontrowersyjnym zagadnieniem będzie wytoczenie powództwa, ponieważ istnieje potrzeba:

[...] rozróżnienia między naruszeniem dobrego imienia osoby prawnej i osób fizycznych, wchodzących w skład organów osoby prawnej, a także osób fizycznych będących pracownikami powodowej spółdzielni. W szczególności rozważenia wymaga, kiedy negatywne wypowiedzi na temat osób fizycznych - wchodzących w skład organów osoby prawnej lub pracowników tej osoby prawnej, mogą prowadzić do naruszenia reputacji samej osoby prawnej ${ }^{8}$.

Pomimo tego, że w orzeczeniu mowa jest o spółdzielni, to powyższe można odnieść również do podmiotów wydających artykuły naukowe. Wnioskując jeszcze dalej, przepisy dotyczące ochrony dóbr osobistych będą miały zastosowanie także do ułomnych osób prawnych, ponieważ do jednostek organizacyjnych niebędących osobami prawnymi, którym ustawa przyznaje zdolność prawną, stosuje się odpowiednio przepisy o osobach prawnych (art. $33^{1}$ k.c.).

Biorąc powyższe pod uwagę, trzeba pamiętać, że odpowiedzialne za naruszenie dóbr osobistych są tylko takie osoby, które decydowały albo współdecydowały o publikacji artykułu, czyli miały istotny udział w decyzji o jego ukazaniu się w danej gazecie. Zastosowanie art. 38 ust. 1 pr. pras. jest możliwe, w zależności od okoliczności, w stosunku do redaktora wydania lub kierownika działu wydawnictwa albo tytułu prasowego, musi natomiast zostać całkowicie wykluczone w stosunku do osób, które nie mając odpowiednich kompetencji ani nie pełniąc właściwej funkcji, związanej z zatrudnieniem na stanowisku kierowniczym, nie miały wpływu na publikację konkretnego materiału w prasie. Osoby niepowiązane stosunkiem przełożenia wobec autora publikacji nie mogą mieć wpływu na decyzję dotyczącą zamieszczenia artykułu w gazecie i nie mogą ponosić odpowiedzialności za skutki jego publikacji ${ }^{9}$.

Ważne jest także, że materiał prasowy, który nie został opublikowany - zarówno gdy został zakwalifikowany do druku, jak i wtedy, gdy będąc przeznaczony przez

6 Tak: wyrok SN z dnia 14 listopada 1986 r., II CR 295/86, OSNCPiUS 1988, nr 2-3, poz. 40. Zob. także: wyrok SN z dnia 24 września 2008 r., II CSK 126/08, OSNC-B 2009, poz. 58, s. 176.

7 Więcej na ten temat zob. A. Chajewska, K. Orlik, [w:] Prawo prasowe. Postepowania sądowe w sprawach prasowych, red. I. Matusiak, K. Orlik, Warszawa 2017, s. 455-456; wyrok SN z dnia 10 listopada 2005 r., V CK 314/05, Legalis; wyrok SN z dnia 22 stycznia 2015 r., I CSK 16/14, Legalis.

8 Tak: wyrok SN z dnia 10 listopada 2005 r., V CK 314/05, Legalis. Por. także: wyrok SN z dnia 22 stycznia 2002 r., II CKN 642/00, MP 2004, nr 6, s. 279.

9 Tak: wyrok SA w Warszawie z dnia 23 stycznia 2013 r., I ACa 1319/12, Legalis. 
autora lub autorów do druku, nie został zakwalifikowany do publikacji - może stanowić źródło naruszenia dóbr osobistych określonej osoby, ale tylko wtedy, jeżeli został ujawniony ${ }^{10}$. Zdarza się czasami, że autorzy udostępniają sobie tzw. maszynopisy artykułów czy publikacji, które zamierzają opublikować. Dlatego konieczne jest wskazanie na tę pozycję w przypisie i oznaczenie, że tekst jest „w druku” lub są to materiały własne, które zostały udostępnione. Właściwy autor danego tekstu łatwo może udowodnić, że są to jego słowa, ponieważ w dzisiejszych czasach rzadko przekazujemy coś ,z rąk do rąk”, zazwyczaj przesyłamy elektronicznie lub przesyłamy pocztą lub kurierem. Ponadto teksty tworzone są prawie zawsze na komputerze, który wskazuje daty zapisu pliku i jego modyfikacji oraz autora (wskazanie na komputer, na którym został napisany artykuł).

\section{POJĘCIE ODPOWIEDZIALNOŚCI NIEMAJĄTKOWEJ}

Kolejny przepis dotyczący naruszenia praw autorskich to art. 24 k.c., zgodnie z którym ten, czyje dobro zostało bezprawnie naruszone, może żądać, żeby osoba (fizyczna, prawna lub ułomna osoba prawna), która dopuściła się naruszenia, zaniechała tego działania, chyba że nie jest ono bezprawne, lub dopełniła czynności potrzebnych do usunięcia jego skutków.

Już na początku warto zauważyć, że wskazuje się określone przesłanki odpowiedzialności, które muszą być spełnione kumulatywnie, z tytułu naruszenia dóbr osobistych (wyszczególnione na podstawie art. 24 k.c.). Są to: posiadanie dobra osobistego, zagrożenie lub naruszenie tego dobra osobistego, a także bezprawność tego zagrożenia lub naruszenia ${ }^{11}$.

Z omawianego przepisu wynika, że w każdym wypadku naruszenia dobra osobistego, a więc bez względu na rodzaj naruszenia i rodzaj dobra, pokrzywdzonemu przysługuje roszczenie, tzn. może on żądać, aby osoba, która jego dobro naruszyła, dokonała takiej czynności lub takich czynności, które będą stanowić ekwiwalent wyrządzonej krzywdy w tym znaczeniu, że niejako zniwelują jej skutki. Rodzaj tych czynności musi być odpowiedni. Niewątpliwie typowym sposobem usunięcia skutków naruszenia dobra osobistego jest złożenie przez sprawcę oświadczenia o treści odpowiedniej do okoliczności sprawy, czyli zawierającego przeproszenie, odwołanie zarzutów. Rodzaj czynności nie wyczerpuje oczywiście zagadnienia odpowiedniości czy adekwatności środka do okoliczności sprawy. Istotna staje się bowiem forma, w jakiej sprawca ma dokonać wybranej czynności, w tym wypad-

${ }^{10}$ Wyrok SA w Gdańsku z dnia 2 czerwca 2010 r., I ACa 382/10, „Przegląd Orzecznictwa Sądu Apelacyjnego w Gdańsku" 2010, nr 3, poz. 5, s. 60.

11 Więcej na ten temat zob. A. Chajewska, K. Orlik, op. cit., s. 456-457. 
ku forma oświadczenia ${ }^{12}$. Ponadto - zgodnie z art. 24 k.c. - osoba, której dobro zostało naruszone, może również żądać zadośćuczynienia pieniężnego lub zapłaty odpowiedniej sumy pieniężnej na wskazany cel społeczny, co zostanie omówione w kolejnym punkcie dotyczącym odpowiedzialności majątkowej.

Poza wymienionymi w art. 24 k.c. środkami niemajątkowej ochrony dóbr osobistych pokrzywdzonemu przysługuje (dodatkowo) ${ }^{13}$ :

[...] możliwość żądania ustalenia na postawie art. 189 k.p.c. (powództwo o ustalenie), że doszło do naruszenia dobra osobistego. W szczególności ustalenie dotyczyć może tzw. faktów prawotwórczych - zdarzeń prawnych powodujących powstanie stosunku prawnego np. naruszeń dóbr osobistych. W dawniejszym orzecznictwie dopuszczalność skorzystania z art. 189 k.p.c. jako środka ochrony dóbr osobistych budziła wątpliwości. Obecnie jednak możliwość taka nie budzi już zastrzeżeń ${ }^{14}$.

Zdaniem P. Sobolewskiego na gruncie wykładni literalnej art. 189 k.p.c. dominujący w orzecznictwie pogląd może budzić pewne wątpliwości:

Przywołany przepis pozwala żądać ustalenia istnienia stosunku prawnego lub prawa, natomiast stwierdzenie naruszenia dobra osobistego, także w sposób bezprawny, nie stanowi stwierdzenia istnienia stosunku prawnego lub prawa. Treścią stosunku prawnego są określone prawa i odpowiadające im obowiązki drugiej strony stosunku. Bezprawne naruszenie dóbr osobistych jest zdarzeniem prawnym, które powoduje powstanie stosunku, którego treścią są obowiązki podmiotu naruszającego dobra osobiste (np. obowiązek usunięcia skutków naruszenia). Stwierdzenie istnienia prawa lub stosunku prawnego miałoby miejsce dopiero w przypadku stwierdzenia przez sąd istnienia określonego obowiązku po stronie podmiotu naruszającego dobra osobiste, a nie samego faktu naruszenia dobra osobistego ${ }^{15}$.

Pogląd ten nie do końca zasługuje na aprobatę, tym bardziej jeśli chcielibyśmy dochodzić naruszenia praw autorskich. Niektóre dobra osobiste nabywamy automatycznie (zdrowie, wolność, wyznanie), natomiast żeby posiadać prawa autorskie do artykułu, musimy go stworzyć/napisać (tak samo jest z wszelką twórczością). Dlatego dochodzenie ustalenia naruszenia praw autorskich można przeprowadzić na podstawie art. 189 k.p.c.

${ }^{12}$ Wyrok SN z dnia 20 listopada 2013 r., I CSK 66/13, LEX nr 1522074.

${ }^{13}$ O subsydiarnym charakterze powództwa o ustalenie zob. postanowienie SN z dnia 29 października 2009 r., III CZP 79/09, Legalis.

${ }_{14}$ Zob. P. Sobolewski, [w:] Kodeks cywilny. Komentarz. Część ogólna. Przepisy wprowadzajace KC. Prawo o notariacie (art. 79-95 i 96-99), red. K. Osajda, Warszawa 2017, komentarz do art. 24, s. 209-210. Zob. także: postanowienie SN z dnia 22 marca 1991 r., III CRN 28/91, Legalis; uchwała SN z dnia 22 września 1995 r., III CZP 118/95, OSNC 1996, nr 1, poz. 7.

15 Tak: P. Sobolewski, op. cit., komentarz do art. 24, s. 209-210. 


\section{POJĘCIE ODPOWIEDZIALNOŚCI MAJĄTKOWEJ}

Ostatnim przepisem stanowiącym podstawę odpowiedzialności cywilnej jest art. 448 k.c., zgodnie z którym w razie naruszenia dobra osobistego sąd może przyznać temu, czyje dobro osobiste zostało naruszone, odpowiednią sumę tytułem zadośćuczynienia pieniężnego za doznaną krzywdę lub na jego żądanie zasądzić odpowiednią sumę pieniężną na wskazany przez niego cel społeczny (środek wskazany także w art. 24 k.c.), niezależnie od innych środków potrzebnych do usunięcia skutków naruszenia. Poza tym w art. 24 ust. 2 k.c. wskazano, że jeśli naruszeniem dóbr osobistych została wyrządzona szkoda majątkowa, to można dochodzić jej naprawienia na zasadach ogólnych. Oznacza to, że możliwe jest zasądzenie odszkodowania.

Należy w tym miejscu wskazać, że zasądzenie odszkodowania jest możliwe po spełnieniu powyższych przesłanek wynikających z art. 24 ust. 1 k.c. Ponadto musimy udowodnić winę, związek przyczynowy oraz szkodę majątkową. Trzeba też wspomnieć, że w praktyce bardzo trudno jest udowodnić szkodę majątkową powstałą z tytułu naruszenia dóbr osobistych, którymi są prawa autorskie, dlatego z odszkodowaniem mamy do czynienia niezwykle rzadko.

Wracając do art. 448 k.c., warto przytoczyć pogląd P. Sobolewskiego, którego zdaniem:

[...] literalna wykładnia art. 448 k.c. nie daje jednoznacznych rezultatów i pozwala na kilka wariantów interpretacyjnych. Szczególne kontrowersje budzi zasada przypisania odpowiedzialności. W piśmiennictwie i orzecznictwie wskazywanych jest pięć wariantów interpretacyjnych ${ }^{16}$.

Zgodnie z orzecznictwem i doktryną dominuje pogląd, iż tylko zawinione naruszenie dobra osobistego uzasadnia zasądzenie zadośćuczynienia i odpowiedniej sumy pieniężnej na wskazany cel społeczny, natomiast dla zasądzenia zadośćuczynienia wystarczający jest jakikolwiek stopień winy (nawet culpa levissima) ${ }^{17}$. Stopień winy sprawcy krzywdy wpływa jednak na wysokość zadośćuczynienia. Jest to jak najbardziej trafny pogląd, ponieważ przesłankami tej odpowiedzialności są: wina, związek przyczynowy i krzywda. Oczywiście są to przesłanki, które muszą być spełnione kumulatywnie, poza tym muszą zostać spełnione przesłanki z art. 24 $\S 1$ k.c. (odpowiedzialności niemajątkowej).

Warto również przytoczyć pozostałe poglądy, które stanowią, że:

${ }_{16}$ Zob. więcej: ibidem, komentarz do art. 448, s. 880.

17 Por. wyrok SN z dnia 5 marca 2010 r., IV CSK 340/09, Legalis; uchwała SN (7) z dnia 9 września 2008 r., III CZP 31/08, OSNC 2009, nr 3, poz. 36; wyrok SN z dnia 11 grudnia 2013 r., IV CSK 188/13, Legalis. 
1) każde naruszenie dobra osobistego uzasadnia zasądzenie zadośćuczynienia i odpowiedniej sumy pieniężnej na wskazany cel społeczny (bez względu na winę sprawcy, bezprawność naruszenia itd.);2) tylko bezprawne naruszenie dobra osobistego uzasadnia zasądzenie zadośćuczynienia i odpowiedniej sumy pieniężnej na wskazany cel społeczny; 3) tylko naruszenie dobra osobistego kwalifikowane jako czyn niedozwolony na gruncie pozostałych przepisów k.c. (bez względu na zasadę przypisania odpowiedzialności) uzasadnia zasądzenie zadośćuczynienia i odpowiedniej sumy pieniężnej na wskazany cel społeczny; [... 5) każda postać winy uzasadnia przyznanie zadośćuczynienia, jednak tylko wina umyślna lub rażące niedbalstwo stanowią podstawę zasądzenia sumy pieniężnej na wskazany cel społeczny ${ }^{18}$.

Nie bez znaczenia jest także to, że art. 448 k.c. należy do tzw. prawa sędziowskiego, którego istotą jest pozostawienie sądowi pewnego marginesu swobody, co nie oznacza oczywiście niczym nieograniczonej arbitralności oceny sędziowskiej ${ }^{19}$. Do poszkodowanego należy wybór, czy w ogóle korzystać z roszczeń przewidzianych w art. 448 k.c. czy wystąpić tylko z roszczeniem o zadośćuczynienie na swoją rzecz bądź tylko z roszczeniem o zasądzenie odpowiedniej sumy pieniężnej na wskazany cel społeczny, czy też wystąpić z obu roszczeniami równocześnie. Natomiast o dalszym losie tych roszczeń będzie decydował sąd. Jeżeli poszkodowany wystąpi tylko o zadośćuczynienie na swoją rzecz i żądanie to okaże się nieuzasadnione, sąd może jedynie oddalić powództwo, i to także wtedy, gdyby uznał za celowe zasądzenie odpowiedniej kwoty pieniężnej na cel społeczny. Wielość środków umożliwiających kompensatę szkody niemajątkowej powinna być przy tym postrzegana jako wyraz szczególnej dbałości ustawodawcy o ochronę dóbr osobistych $^{20}$.

W zdaniu drugim art. 448 k.c. jest odwołanie do art. $445 \S 3$ k.c., który przesądza o dziedziczeniu roszczenia. Zgodnie z tym przepisem roszczenie o zadośćuczynienie przechodzi na spadkobierców tylko wtedy, gdy zostało uznane na piśmie albo gdy powództwo zostało wytoczone za życia poszkodowanego.

Wracając do odpowiedzialności majątkowej, należy zauważyć, że aby wskazać odpowiednią sumę, która będzie wskazywać na odpowiednie zadośćuczynienie za doznaną krzywdę spowodowaną naruszeniem dóbr osobistych, trzeba mieć na uwadze rodzaj dobra, które zostało naruszone, oraz charakter, stopień nasilenia i czas trwania doznawania przez osobę, której dobro zostało naruszone, ujemnych przeżyć psychicznych spowodowanych naruszeniem (krzywda). Oceniając daną sytuację, musimy wziąć pod uwagę stopień winy osoby naruszającej dobra osobi-

${ }^{18}$ Zob. więcej: P. Sobolewski, op. cit., komentarz do art. 448, s. 880.

19 Zob. także: wyrok TK z dnia 7 lutego 2005 r., SK 49/03 (Dz.U. z 2005 r., nr 27, poz. 233), zgodnie z którym art. 448 k.c. w części, w jakiej zawiera zwrot „sąd może przyznać”, jest zgodny $\mathrm{z}$ art. 30, art. 32 ust. $1 \mathrm{i}$ art. 47 Konstytucji RP oraz nie jest niezgodny z art. 77 ust. 1 Konstytucji RP.

${ }^{20}$ Uchwała SN (7) z dnia 9 września 2008 r., III CZP 31/08, OSNC 2009, nr 3, poz. 36, s. 1. 
ste, cel, który zamierzała ona osiągnąć, podejmując działanie naruszające te dobra, i korzyść majątkową, jaką w związku z tym działaniem uzyskała lub spodziewała się uzyskać21. Poza tym warto zastanowić się, jakie znaczenie wśród powyższych wartości będą miały te materialne, tj. cena za czasopismo, w którym artykuł został opublikowany, wynagrodzenie, jakie autor otrzymał, a także dochód wydawnictwa z tytułu opublikowania artykułu. $Z$ pewnością te wartości również są istotne przy określaniu odpowiedniej sumy pieniężnej. Na koniec trzeba zauważyć, że roszczenia te nie mogą być zbyte, chyba że są wymagalne, zostały przyznane na piśmie lub w prawomocnym wyroku.

\section{POJĘCIE ODPOWIEDZIALNOŚCI OSÓB BIORĄCYCH UDZIAŁ W PROCESIE WYDAWNICZYM}

W redakcji odpowiedzialność osób biorących udział w procesie wydawniczym jest zróżnicowana. Zarówno w odniesieniu do wydawcy, jak i redaktora naczelnego podstawy ich odpowiedzialności nie musi stanowić ich własne działanie, tj. wpływanie na treść publikacji. W przypadku redaktora naczelnego wystarczy, aby podejmował on decyzję o dokonaniu publikacji. Natomiast wydawca odpowiada niezależnie od odpowiedzialności innych osób. Do naruszenia dobra osobistego pokrzywdzonego dochodzi $\mathrm{w}$ wyniku popełnienia czynu niedozwolonego wyrażającego się w ,spowodowaniu opublikowania materiału prasowego", niezależnie od udziału poszczególnych osób w odpowiednich czynnościach (ich sekwencji) prowadzących do ostatecznego opublikowania materiału prasowego. Konstrukcyjna jedność deliktu (spowodowanie opublikowania materiału prasowego), krzywdy i możliwości żądania zadośćuczynienia za tę krzywdę wyłączają dopuszczalność różnicowania zakresu odpowiedzialności osób określonych w art. 38 ust. 1 pr. pras. w odniesieniu do zapłaty zadośćuczynienia ${ }^{22}$.

Biorąc pod uwagę powyższe orzeczenie, warto zauważyć, że zdarza się tak, iż podczas prac $\mathrm{w}$ redakcji $\mathrm{w}$ tekście autora zostanie dokonana poprawka, która w istotny sposób zmienia treść, wprowadza błąd merytoryczny albo np. powoduje błąd w imieniu, nazwisku lub tytule naukowym autora. W takiej sytuacji odpowiedzialność za błąd w tekście ponosi redakcja. Pytanie jednak, czy będzie to redaktor merytoryczny lub polonista, którzy najczęściej współpracują z wydawnictwem, czy też redaktor naczelny, który decydując o publikacji, sam dokonał błędnej po-

${ }^{21}$ Tak: wyrok SA we Wrocławiu z dnia 28 marca 2012 r., I ACa 162/12, Legalis. Zob. także: A. Cisek, W. Dubis, [w:] Kodeks cywilny. Komentarz, red. E. Gniewek, P. Machnikowski, Warszawa 2017, komentarz art. 448, nb 7, s. 954.

22 Tak: wyrok SA w Warszawie z dnia 15 stycznia 2013 r., I ACa 1040/12, LEX nr 1322800. Zob. także: wyrok SN z dnia 26 września 2002 r., III CKN 1037/00, Legalis. 
prawki albo nie zauważył błędu, który popełnili jego współpracownicy (redaktor merytoryczny, polonista). W takiej sytuacji odpowiedzialność poniesie przede wszystkim osoba decydująca o publikacji w danym czasopiśmie lub książce. A na jakich zasadach będą odpowiadały wówczas osoby współpracujące z wydawnictwem? W zakresie odpowiedzialności majątkowej będzie to odpowiedzialność solidarna. Ponadto wydaje się, że niezbędne będzie opublikowanie sprostowania na zasadach określonych powyżej. Zagadkowe jest jednak, czy w publikowanym sprostowaniu będzie można wskazać, że to osoba współpracująca z wydawnictwem spowodowała wprowadzenie błędu w publikowanym materiale. Na pewno przed udzieleniem odpowiedzi na to pytanie niezbędne będzie dokładne zapoznanie się z umową podpisaną między tymi osobami. Zazwyczaj jest tak, że zamiast wskazywać na konkretną osobę, wydawnictwo zamieszcza typowe sprostowanie, a osoba współpracująca z wydawnictwem ponosi odpowiedzialność majątkową na podstawie podpisanej umowy.

\section{POJĘCIE ODPOWIEDZIALNOŚCI OSÓB TRZECICH}

Autor, podpisując umowę wydawniczą, przenosi na wydawcę wyłączne prawo wydawania utworu w postaci książkowej oraz wykorzystywania go na określonych w umowie polach eksploatacji. Oznacza to, że przenosi na wydawnictwo autorskie prawa majątkowe, za co przysługuje mu prawo do wynagrodzenia ${ }^{23}$. Oczywiście autor nadal może korzystać z praw osobistych, ponieważ są one niezbywalne. Trzeba jednak pamiętać, że to osoba posiadająca prawa majątkowe kontroluje wykorzystanie utworu ${ }^{24}$. Dlatego w sytuacji, gdy czyjeś prawo autorskie zostało naruszone opublikowaniem przez wydawcę materiału, może on złożyć do niego roszczenie. „Odpowiedzialność wydawcy ma charakter bezwarunkowy, czyli odpowiada prawnie za treść wszystkich publikacji prasowych w danym periodyku"25.

Biorąc pod uwagę powyższe, w sytuacji, gdy nasze prawo autorskie zostało naruszone, pozywamy/wzywamy do polubownego załatwienia sprawy wydawnictwo, w którym ukazał się tekst. Właściwy wtedy będzie zazwyczaj sąd okręgowy (zob. art. 17 pkt 1 i 3 k.p.c. ${ }^{26}$ ), ponadto bardzo często również w umowie wydawniczej strony określają sąd właściwy. Z tego względu bardzo ważna jest treść umowy

${ }^{23}$ U. Lawina, Autor musi zadbać, aby umowa z wydawca strzegła też jego interesów, 02.06.2015, http://serwisy.gazetaprawna.pl/prawo-autorskie/artykuly/874948,autor-musi-zadbac-aby-umowa-z-wydawca-strzegla-tez-jego-interesow.html [dostęp: 02.06.2018].

${ }^{24}$ Umowa o przekazaniu praw $i$ umowa licencyjna, https://prawokultury.pl/kurs/umowa-o -przekazaniu-praw-i-umowa-licencyjna [dostęp: 10.02.2018].

25 A. Chajewska, K. Orlik, op. cit., komentarz do art. 38, s. 32.

${ }^{26}$ Ustawa z dnia 17 listopada 1964 r. - Kodeks postępowania cywilnego (t.j. Dz.U. z 2018 r., poz. 155 ze zm.), dalej jako: k.p.c. 
wydawniczej zawieranej pomiędzy wydawnictwem a autorem. Od tego zależy też, czy to autor osobiście występuje z roszczeniem czy robi to wydawnictwo, w którym został opublikowany artykuł. Od umowy zależą także czasami dalsze losy, tj. czy autor i wydawnictwo są współpozwanymi w procesie, czy będzie miała miejsce np. interwencja uboczna. Oddziałuje to również na rodzaj orzeczenia wydanego przez sąd. Sąd, przyznając ochronę niemajątkową, kieruje się zasadą proporcjonalności tak, aby zastosowany środek ochrony był przydatny do osiągnięcia zakładanego celu (usunięcia skutków dokonanego naruszenia), istniała konieczność zastosowania w danym stanie faktycznym żądanego środka ochrony oraz aby orzeczony środek ochrony pozostawał w odpowiedniej proporcji do zakładanego celu. Środki ochrony naruszonego dobra osobistego muszą być adekwatne do samego naruszenia i jego skutków oraz stosowane z uwzględnieniem całokształtu okoliczności sprawy ${ }^{27}$.

Ponadto autor, przystępując do wydania artykułu naukowego, musi się upewnić, czy nie narusza cudzych praw autorskich, aby to on nie został oskarżony. Co więcej, bardzo często autor podpisuje oświadczenie lub zawarte jest ono w treści umowy, że tekst, który złożył do publikacji, nie narusza praw osób trzecich (lub podobnej treści). Dzięki temu wydawnictwo może nie ponosić odpowiedzialności za naruszenie praw osób trzecich. Dodatkowo trzeba bardzo uważnie przeczytać i przeanalizować warunki umowy wydawniczej, ponieważ to od niej najwięcej zależy. Należy negocjować warunki z wydawnictwem, prosić o ich wyjaśnienie, traktować umowę z wydawnictwem jak każdą inną umowę cywilnoprawną. Dzięki temu unikniemy większości nieporozumień, które mogą powstać po opublikowaniu artykułu naukowego.

\section{POJĘCIE AUTOPLAGIATU}

Niezwykle ciekawym i trudnym zagadnieniem, które trzeba poruszyć, jest tzw. autoplagiat. Występuje on, gdy autor wydaje dwie publikacje i w obu posługuje się tym samym tekstem, nie wstawiając cudzysłowu lub przypisu. Jest to sytuacja trudna do opiniowania, ponieważ z jednej strony jeden tekst powinien być publikowany raz, ale z drugiej to od autora zależy gdzie i ile razy jego tekst zostanie opublikowany. Sam autor nie może okraść się z przysługujących mu praw autorskich $^{28}$. Warto zauważyć, że wydawnictwo także powinno unikać takich sytuacji, ponieważ czytelnik, który kupi obie publikacje, może poczuć się oszukany. Trzeba zauważyć, że każda pozycja ma służyć czemuś innemu; wydawnictwo, nawet

${ }^{27}$ Wyrok SA w Warszawie z dnia 12 września 2013 r., I ACa 324/13, LEX nr 1392085. Por. także: wyrok SA w Łodzi z dnia 27 lutego 2014 r., I ACa 1140/13, LEX nr 1444766.

${ }_{28}$ Zob. więcej: J.M. Doliński, Czy autoplgiat jest plagiatem?, „Edukacja Prawnicza” 2012, nr 3, s. 35-38. 
zmieniając serię książki, zestawiając dany tekst z innymi, sprawia, że może on mieć inny wydźwięk, a czasami też znaczenie. Ponadto autor, który popełnił autoplagiat w dwóch różnych wydawnictwach, odpowiada ,z tytułu naruszenia autorskich praw majątkowych i odpowiedzialności ex contractu wobec wydawcy, który uprzednio nabył prawa autorskie do utworu na mocy zawartej umowy wydawniczej" ${ }^{29}$. Co istotne, zazwyczaj dwa teksty, nawet zawierające elementy autoplagiatu, nie są identyczne, zawierają tylko pewne elementy wspólne.

Autoplagiat nie stanowi naruszenia praw autorskich, ale warto wskazać tutaj wyrok WSA w Warszawie z dnia 15 marca 2017 r. ${ }^{30}$, zgodnie z którym ubiegający się o nadanie stopnia naukowego doktora habilitowanego przedstawił pracę naukową, która była przedstawiona w poprzednim postępowaniu habilitacyjnym, co zdaniem sądu jest naganną postawą etyczną habilitanta. Taka sytuacja jest przejawem naruszenia „dobrych obyczajów w nauce”. Co więcej:

[...] zdaniem Centralnej Komisji, uchwała Rady Wydziału o odmowie nadania stopnia doktora habilitowanego $\mathrm{w}$ dyscyplinie nauki o zarządzaniu była w pełni zasadna i merytorycznie trafna, o czym świadczy m.in. niespełnienie przez skarżącego ustawowego wymogu o znacznym wkładzie w rozwój wskazanej dyscypliny naukowej. Wyjaśnienia kandydata odnośnie stawianych mu w recenzjach zarzutów nie wnoszą do sprawy nowych, istotnych elementów. Argumenty dotyczące braku docenienia jakości jego osiągnięcia naukowego są bezzasadne. Treść odwołania oraz lektura dokumentacji, w tym tzw. osiągnięcia naukowego, wskazuje, że wnioskodawca nie wie lub nie rozumie, na czym polegają wymagania dotyczące tzw. monografii habilitacyjnej.

Adekwatne orzeczenie sąd wydał w przypadku postępowania dotyczącego nadania tytułu naukowego profesora - oznaczono to jako „posthabilitacyjny autoplagiat”, ponadto pretendujący do tytułu dopuścił się innych autoplagiatów, często o charakterze nienaukowym ${ }^{31}$.

\section{PODSUMOWANIE}

Podsumowując powyższe rozważania, należy wskazać, że mamy dwa rodzaje roszczeń niemajątkowych (zaniechanie, usunięcie skutków naruszenia) oraz trzy rodzaje roszczeń majątkowych (zadośćuczynienie pieniężne za doznaną krzywdę, odpowiednia suma pieniężna na wskazany cel społeczny, odszkodowanie). W sy-

${ }^{29}$ J. Banasiuk, J. Sieńczyło-Chlabicz, Pojęcie i istota zjawiska autoplagiatu w twórczości naukowej, „Państwo i Prawo” 2012, z. 3, s. 6-19.

${ }^{30}$ II SA/Wa 692/16, LEX nr 2286177.

${ }^{31}$ Zob. wyrok WSA w Warszawie z dnia 7 grudnia 2007 r., I SA/Wa 1067/07, LEX nr 433759. 
tuacji, gdy sąd uzna, że środki niemajątkowe są niewystarczające do zaspokojenia powództwa, sięga po majątkowe środki ochrony dóbr osobistych przewidziane w art. 448 k.c. To od autora zależy, jakiego zadośćuczynienia lub zadośćuczynień będzie żądał od pozwanego, co zazwyczaj jest związane z wyżej wymienionymi przesłankami.

Wcześniej pogląd ten budził wątpliwości, ale zostały one rozwiane po wydaniu przez Sąd Najwyższy stosownej uchwały ${ }^{32}$. Zgodnie z nią roszczenia przewidziane w art. 448 k.c. stanowią dopełnienie wachlarza środków ochrony dóbr osobistych, których zastosowanie powinno być oceniane z uwzględnieniem potrzeby ich wykorzystania w danym stanie faktycznym. Dopiero w razie naruszenia konkretnego dobra osobistego można bowiem ocenić, czy zachodzi w ogóle potrzeba sięgania po roszczenia wskazane w art. 448 k.c., czy zastosowanie jednego z nich pozwoli osiągnąc stan rokujący osiągnięcie pełnej ochrony czy też konieczne będzie zastosowanie w tym celu obu środków.

Niewątpliwie publikacja artykułu naukowego budzi wiele wątpliwości, na które odpowiedzi nie znajdziemy w żadnej z ustaw. Wydaje się, że ustawodawca powinien w tym temacie zawęzić margines swobody zawierania umowy wydawniczej, ponieważ często $w$ takich sytuacjach najbardziej poszkodowany jest autor. Zazwyczaj nie wie on, jakie zagrożenia wiążą się z publikacją artykułu naukowego i zgadza się na warunki wydawnictwa.

Ponadto w ustawach chroniących prawa autorskie (pr. pras., pr. aut.) brak jest unormowania niektórych definicji. Jak wskazano powyżej, wiele z nich jest niejasnych, a niektórych nie ma w ogóle (np. definicji autoplagiatu). Dlatego sugeruję ich doprecyzowanie lub dodanie. Problemem jest także wielość ustaw. Niestety, omawiając naruszenie praw autorskich, musimy sięgać do kilku ustaw, w których znajdują się unormowania poszczególnych zagadnień.

Co więcej, właściwy do rozpoznawania spraw o prawa niemajątkowe i łącznie z nimi dochodzone roszczenia majątkowe, a także o roszczenia wynikające z Prawa prasowego, jest sąd okręgowy (art. 17 pkt 1 i 3 k.p.c.). Jest to sąd, który rozpoznaje wiele spraw jako druga instancja, co pokazuje, jak skomplikowanym zagadnieniem jest powyżej zaprezentowany temat.

Biorąc pod uwagę powyższe spostrzeżenia, konieczna jest konkluzja, że odpowiedzialność za opublikowanie artykułu naukowego to bardzo trudny temat. Należy jednocześnie podkreślić, że powyżej zostały omówione tylko zasady odpowiedzialności cywilnej, a przecież jest jeszcze odpowiedzialność karna oraz dyscyplinarna. 


\section{BIBLIOGRAFIA}

Banasiuk J., Sieńczyło-Chlabicz J., Pojęcie i istota zjawiska autoplagiatu w twórczości naukowej, „Państwo i Prawo” 2012, z. 3.

Chajewska A., Orlik K., [w:] Prawo prasowe. Postępowania sadowe w sprawach prasowych, red. I. Matusiak, K. Orlik, Warszawa 2017.

Cisek A., Dubis W., [w:] Kodeks cywilny. Komentarz, red. E. Gniewek, P. Machnikowski, Warszawa 2017.

Doliński J.M., Czy autoplgiat jest plagiatem?, „Edukacja Prawnicza” 2012, nr 3.

Kodeks cywilny. Komentarz, red. E. Gniewek, P. Machnikowski, Warszawa 2017.

Lawina U., Autor musi zadbać, aby umowa z wydawca strzegła tė̇ jego interesów, 02.06.2015, http:// serwisy.gazetaprawna.pl/prawo-autorskie/artykuly/874948,autor-musi-zadbac-aby-umowa-z-wydawca-strzegla-tez-jego-interesow.html [dostęp: 02.06.2018].

Postanowienie SN z dnia 22 marca 1991 r., III CRN 28/91, Legalis.

Postanowienie SN z dnia 29 października 2009 r., III CZP 79/09, Legalis.

Prawo prasowe. Komentarz, red. B. Kosmus, G. Kuczyński, Warszawa 2013.

Sobczak J., Prawo prasowe. Komentarz, Warszawa 2008.

Sobolewski P., [w:] Kodeks cywilny. Komentarz. Część ogólna. Przepisy wprowadzające KC. Prawo o notariacie (art. 79-95 i 96-99), red. K. Osajda, Warszawa 2017.

Uchwała SN z dnia 22 września 1995 r., III CZP 118/95, OSNC 1996, nr 1, poz. 7.

Uchwała SN (7) z dnia 9 września 2008 r., III CZP 31/08, OSNC 2009, nr 3, poz. 36.

Umowa o przekazaniu praw i umowa licencyjna, https://prawokultury.pl/kurs/umowa-o-przekazaniu -praw-i-umowa-licencyjna [dostęp: 10.02.2018].

Ustawa z dnia 23 kwietnia 1964 r. - Kodeks cywilny (t.j. Dz.U. z 2018 r., poz. 1025 ze zm.).

Ustawa z dnia 17 listopada 1964 r. - Kodeks postępowania cywilnego (t.j. Dz.U. z 2018 r., poz. 155 ze zm.).

Ustawa z dnia 26 stycznia 1984 r. - Prawo prasowe (Dz.U. nr 5, poz. 24 ze zm.).

Ustawa z dnia 4 lutego 1994 r. o prawie autorskim i prawach pokrewnych (t.j. z 2017 r., poz. 880 ze zm.).

Wyrok SA w Gdańsku z dnia 2 czerwca 2010 r., I ACa 382/10, „Przegląd Orzecznictwa Sądu Apelacyjnego w Gdańsku” 2010, nr 3, poz. 5.

Wyrok SA we Wrocławiu z dnia 28 marca 2012 r., I ACa 162/12, Legalis.

Wyrok SA w Warszawie z dnia 15 stycznia 2013 r., I ACa 1040/12, LEX nr 1322800.

Wyrok SA w Warszawie z dnia 23 stycznia 2013 r., I ACa 1319/12, Legalis.

Wyrok SA w Warszawie z dnia 12 września 2013 r., I ACa 324/13, LEX nr 1392085.

Wyrok SA w Łodzi z dnia 27 lutego 2014 r., I ACa 1140/13, LEX nr 1444766.

Wyrok SN z dnia 14 listopada 1986 r., II CR 295/86, OSNCPiUS 1988, nr 2-3, poz. 40.

Wyrok SN z dnia 22 stycznia 2002 r., II CKN 642/00, MP 2004, nr 6.

Wyrok SN z dnia 26 września 2002 r., III CKN 1037/00, Legalis.

Wyrok SN z dnia 10 listopada 2005 r., V CK 314/05, Legalis.

Wyrok SN z dnia 24 września 2008 r., II CSK 126/08, OSNC-B 2009, poz. 58.

Wyrok SN z dnia 5 marca 2010 r., IV CSK 340/09, Legalis.

Wyrok SN z dnia 20 listopada 2013 r., I CSK 66/13, LEX nr 1522074.

Wyrok SN z dnia 11 grudnia 2013 r., IV CSK 188/13, Legalis.

Wyrok SN z dnia 22 stycznia 2015 r., I CSK 16/14, Legalis.

Wyrok TK z dnia 7 lutego 2005 r., SK49/03 (Dz.U. z 2005 r., nr 27, poz. 233).

Wyrok WSA w Warszawie z dnia 7 grudnia 2007 r., I SA/Wa 1067/07, LEX nr 433759.

Wyrok WSA w Warszawie z dnia 15 marca 2017 r., II SA/Wa 692/16, LEX nr 2286177. 
Pobrane z czasopisma Studenckie Zeszyty Naukowe http://szn.umcs.pl

Data: 26/04/2023 09:28:51

Odpowiedzialność cywilna za opublikowanie artykułu naukowego

\section{SUMMARY}

Civil responsibility for publishing a scientific article is a vague and difficult subject. In Article 38 of the Act - Press Law it is not clearly defined who and when is responsible if copyright is infringed. This article is aimed at trying to indicate when someone's copyright is infringed, what to do if they are infringed, who is responsible for such a violation, and warn authors publishing their scientific article against such liability.

Keywords: civil responsibility; infringed; press law 